\title{
Akut retinanekrózis és ischaemiás stroke társulása
}

\author{
Magyar Márton dr. ${ }^{1}$ - Gunda Bence dr. ${ }^{2}$ - Rudas Gábor dr. ${ }^{3}$ \\ Resch Miklós dr. ${ }^{1}$ - Nagy Zoltán Zsolt dr. ${ }^{1}$ - Dohán Judit dr. ${ }^{1}$
}

\author{
${ }^{1}$ Semmelweis Egyetem, Általános Orvostudományi Kar, Szemészeti Klinika, Budapest \\ ${ }^{2}$ Semmelweis Egyetem, Általános Orvostudományi Kar, Neurológiai Klinika, Budapest \\ ${ }^{3}$ Semmelweis Egyetem, Általános Orvostudományi Kar, Orvosi Képalkotó Klinika, \\ Neuroradiológiai Tanszék, Budapest
}

\begin{abstract}
A varicella zoster vírus (VZV-) fertőzés típusos első megjelenése a bárányhimlő, később a reaktiváció során a herpes zoster. Szemészeti tünet az V/I-es agyideget érintő zoster esetén gyakori. A legrettegettebb szemészeti manifesztáció az akut retinanekrózis, mely fulmináns lefolyású, és súlyos szöveti destrukciót, valamint jelentős funkcionális károsodást, gyakran vakságot hagy maga után. Központi idegrendszeri vascularis érintettség előfordulhat bárányhimlőhöz társulóan vagy a későbbi reaktivációk során is, súlyos következményekhez vezetve. A Semmelweis Egyetem Szemészeti Klinikáján akut retinanekrózis tünetével érkező 65 éves férfi esetét ismertetjük. Az Amerikai Szemorvostársaság (AAO) diagnosztikus kritériumainak mindenben megfelelő klinikai kép alapján azonnal indított adekvát dózisú antivirális kezelés mellett 3 nap múlva, contralateralis hemiparesis hátterében, a képalkotó vizsgálat ipsilateralis ischaemiás stroke-ot igazolt. Intraocularis mintából PCR-vizsgálat bizonyította a vírus jelenlétét. Liquormintában enyhe antiVZV-IgA-pozitivitás mutatkozott. Az aktuális szemészeti betegség és a stroke társulásának hátterében az észlelt paraméterek, valamint a releváns irodalmi adatok alapján a varicella zoster vírus okozta vasculopathiát valószínúsítettük. Gyermekkorban ez az ischaemiás stroke leggyakoribb oka, felnőttkorban pedig az V/I-es agyideg herpeses érintettsége esetén négy és félszeres a kockázat stroke kialakulására. A VZV-reaktiváció okozta akut retinanekrózis és a stroke társulásának lehetősége, bár ismert a nemzetközi irodalomban, magyar szakirodalom tudomásunk szerint eddig nem tárgyalta, ez kiemeli esetünk közlésének jelentőségét.
\end{abstract}

Orv Hetil. 2021; 162(48): 1940-1945.

Kulcsszavak: akut retinanekrózis, varicella zoster vírus, stroke

\section{Association of acute retinal necrosis with ischemic stroke}

The typical first onset of varicella zoster virus (VZV) infection is chickenpox, later herpes zoster during reactivation. Ophthalmic symptoms are common in herpes zoster affecting the V/I cranial nerve. The most dreaded ophthalmic manifestation is acute retinal necrosis, which has a fulminant course and leaves severe tissue damage as well as significant functional impairment, often blindness. Vascular involvement in the central nervous system may occur in association with chickenpox or during subsequent reactivations leading to severe consequences. We report the case of a 65-year-old male patient with symptoms of acute retinal necrosis at the Department of Ophthalmology, Semmelweis University. The clinical picture fulfilled the diagnostic criteria of the American Academy of Ophthalmology (AAO) and after 3 days of the immediately initiated adequate therapy, contralateral hemiparesis appeared, that was confirmed as an ipsilateral stroke by imaging study. The PCR analysis of an intraocular sample confirmed the presence of VZV. Mild anti-VZV IgA positivity was observed in the cerebrospinal fluid sample. Based on the current ophthalmic disease, the associated stroke alongside with the relevant literature data, varicella zoster vasculopathy was probable. VZV vasculopathy is the most common cause of ischemic stroke in childhood and in adulthood herpetic involvement of the $\mathrm{V} / \mathrm{I}$ cranial nerve elevates 4.5 times the risk of stroke formation. Though the possible association of acute retinal necrosis and stroke caused by VZV reactivation is known in the international literature, to the best of our knowledge it has not been discussed in Hungary so far, which highlights the importance of reporting our case.

Keywords: acute retinal necrosis syndrome, varicella zoster virus, stroke

Magyar M, Gunda B, Rudas G, Resch M, Nagy ZZs, Dohán J. [Association of acute retinal necrosis with ischemic stroke]. Orv Hetil. 2021; 162(48): 1940-1945.

(Beérkezett: 2021. március 24.; elfogadva: 2021. május 4.) 


\section{Rövidítések}

$\mathrm{AAO}=$ (American Academy of Ophthalmology) Amerikai Szemorvostársaság; $\mathrm{CMV}=$ cytomegalovirus $; \mathrm{CT}=($ computed tomography) komputertomográfia; DNS = dezoxiribonukleinsav; $\mathrm{EBV}=$ Epstein-Barr-vírus; HIV = (human immunodeficiency virus) emberi immunhiányt előidéző vírus; HSV = herpes simplex vírus; $\mathrm{Ig}=$ immunglobulin; $\mathrm{MR}=$ mágneses rezonancia; $\mathrm{PCR}=$ (polymerase chain reaction) polimerázláncreakció; $\mathrm{VZV}=$ varicella zoster vírus

A varicella zoster vírus (VZV) a humán herpesvírusok családjának 5. szerotípusa. Kizárólag emberi megbetegedést okozó neurotropikus vírus. A primer infekció a legtöbbször gyermekkorban jelentkezik bárányhimlő formájában, majd a vírus latens fázisba kerül, és a leggyakrabban érző ganglionokban perzisztál. A reaktiváció tünetei az adott ganglionnak megfelelően, egy vagy néhány dermatoma érintettségével a középvonalat respektálva mutatkoznak. A jellemző bőrtünetek a betegséget könnyen felismerhetővé teszik, ritka esetben a reaktiváció erupciók nélkül is (zoster sine herpete) jelentkezhet [1]. A vírus a reaktiváció során a mucocutan jeleken túl az idegek, illetve erek mentén terjedve mélyebb szöveti, szervi (fül-orr-gégészeti, szemészeti, központi idegrendszeri, illetve vascularis) tüneteket okozhat.

Szemészeti érintettség esetén a leggyakoribb blepharitis és conjunctivitis a szokványos mucocutan érintettség részjelenségei. A szaruhártya érintettsége jellegzetes dendritikus fekélyként mutatkozik, melyet a mélyebb szöveti érintettség stromalis disciformis keratitisként és endothelitisként már részben immunmediált mechanizmussal követ. Ritkábban felismert az összefüggés a scleritis és a neuritis retrobulbaris, valamint az orbita szöveteinek gyulladása esetén. A trigeminus nervus nasociliaris ágának érintettsége esetén (orrcsúcs laesiókkal: Hutchinson-jel) minden esetben intraocularis manifesztációval kell számolni. Granulomatosus iridocyclitis jelenik meg, az iriserek obliteratiójával és szöveti atrophiával. A trabecularis hálózat érintettsége miatt másodlagos szemnyomás-emelkedés kíséri. A hátsó szegmens érintettsége típusos esetben akut retinanekrózis formájában jelenik meg. A szerencsére ritka, de rettegett kórkép rapidan progresszív, akár fulmináns lefolyású, retinalis és vascularis gyulladással jár, az erek gyors elzáródásával akut ischaemiához és a retina atrophiájához, leválásához vezet, melyhez gyakran társul a látóidegfó gyulladása is. A legtöbb esetben gyorsan bekövetkező súlyos látásromlást, akár vakságot okoz. A gyors felismerés és kezelésbe vonás érdekében az Amerikai Szemorvostársaság (AAO) a típusos klinikai képet diagnosztikus kritériumrendszerbe foglalta [2]. A kritériumok fennállása esetén azonnal vírusgátló kezelést kell indítani (a vér-szem gát miatt a központi idegrendszeri érintettséggel azonos dózisban: $10 \mathrm{mg} /$ tskg, naponta $3 \times$ intravénásan) [3]. Nehéz differenciáldiagnosztikai kérdést vethet fel, hogy a herpesvíruscsalád intraocularis manifesztációinak klinikai tünetei egymástól nem különíthetôk el, a terápiás érzékenység tekintetében viszont alapvető különbség van: CMV-infekció esetén az aciklovirterápia hatástalan, VZV esetében a HSV-infekció kezeléséhez képest dupla dózis szükséges. Ez indokolttá teheti a klinikai tüneteken túl az intraocularis mintából végzett vírusazonosítást PCRmódszerrel.

A Semmelweis Egyetem Szemészeti Klinikájának ambulanciáján jó általános állapotú, 65 éves férfi beteg jelentkezett, 1 hete fokozódó, bal szemet érintő látásromlással. Panaszait megelőzően 3 hete fennálló, azonos oldalra lokalizált, szokatlanul erős, spontán nem szűnő fejfájása volt. Anamnézisében inzulinterápiával jól egyensúlyban tartott, szövődménymentes diabetes mellitus és gyógyszeresen kezelt hypertonia szerepelt. A szemészeti vizsgálat során az akut retinanekrózis típusos, AAOkritériumoknak megfelelő és súlyos klinikai képét láttuk (1. ábra). Ennek alapján azonnal, osztályos felvétel mellett, $10 \mathrm{mg} /$ tskg dózisban naponta $3 \times$ intravénásan alkalmazott aciklovirkezelést indítottunk. A felvétellel egyidejúleg a kezelés kontraindikációit kizártuk; a beteg ismert allergiával nem rendelkezett, a sürgősséggel elvégzett laboratóriumi vizsgálatok során vérképelemei, vesefunkciója, májfunkciója, a szérumelektrolitok, a vércukor- és vizeletvizsgálat paraméterei egyaránt élettaniak voltak. Felvételekor sürgős szerológiai vizsgálatot kezdeményeztünk, amely magas titerü VZV-IgG-pozitivitást, -IgA-, -IgM-negativitást mutatott, korábban lezajlott VZV-fertőzöttséget igazolva. Az elvégzett IgA-szerológia nem jelzett egyéb fertőzöttséget (Toxoplasma, HSV1, HSV2, CMV, EBV, Treponema pallidum, HIV, Mycobacterium tuberculosis tekintetében). A kezelés mellett kétnaponta ellenőriztük a laboratóriumi paramétereket, melyekben kóros eltérést nem észleltünk. A harmadik napra a retina kifejezett ischaemiája alakult ki. A retina erei a látóidegfőbőll való kilépéstől kezdődően fehéres, elzárt „ghost” erekként mutatkoztak (2., 3. ábra). A kezelés megkezdését követően 72 órával a betegnél hirtelen contralateralis (jobb oldali) hemiparesis és facialis paresis tünetei alakultak ki. Azonnali ellátásra a Semmelweis Egyetem Sürgősségi Betegellátó Osztályára irányítottuk mentővel. Az akut koponya-CT-vizsgálat intracranialis vérzést nem igazolt, a klinikai tünetek alapján bal féltekei ischaemiás stroke-ot véleményeztek; thrombolysist végeztek eredménytelenül, a beteg állapotában javulás nem következett be. Az intracranialis kórfolyamat miatt a páciens a Neurológiai Klinika gondozásába került. A további kezelésről való döntés érdekében a kórokozó igazolására csarnokvízmintából elvégeztük sürgős PCRvizsgálatát, mellyel a VZV-DNS magas titerü jelenlétét igazoltuk intraocularisan. A kontroll-laborvizsgálat alapján a beteg vérképe és vesefunkciói változatlanul a normáltartományban voltak, gyógyszermellékhatásra nem utaltak, ezért szemészeti oldalról az igazolt szembetegség adekvát kezelésének folytatását tartottuk szükségesnek. A páciens neurológiai gondozása során a megkezdett antivirális kezelést folytatták változatlan dózisban, 


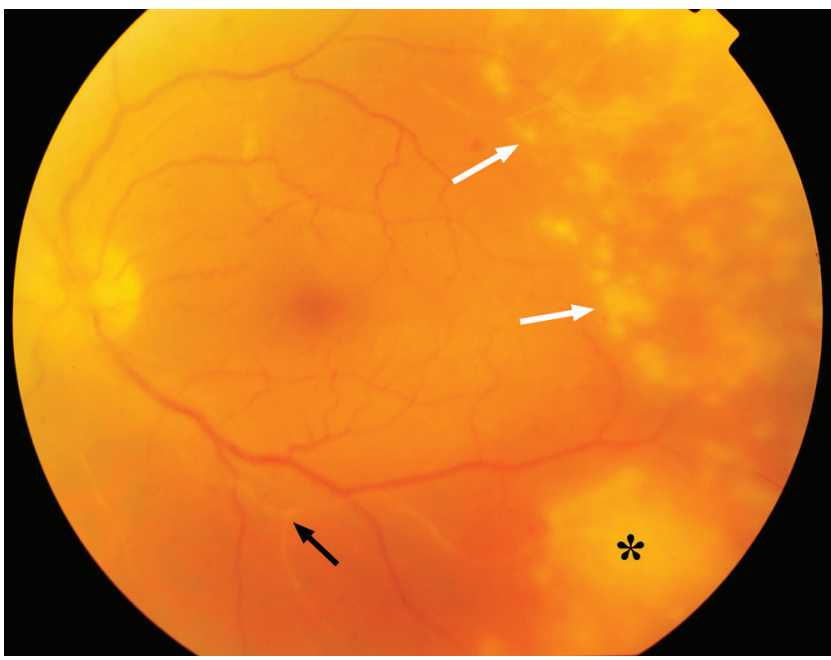

1. ábra

Szemfenéki kép: (hátsó pólus) a temporalis periférián több ki sebb gócú (fehér nyilak), az alsó periférián részben konfluáló (csillag), körkörösen terjedő, fehéres retinalis beszűrődések. Az alsó és felső artériás érágban (fekete nvíl) a véroszlop nem folytonos, a periféria felé fokozatosan elzártnak mutatkozik (obstrukció). A fotó kissé homályosabb megjelenése az üvegtesti sejtes kiszórásból adódik

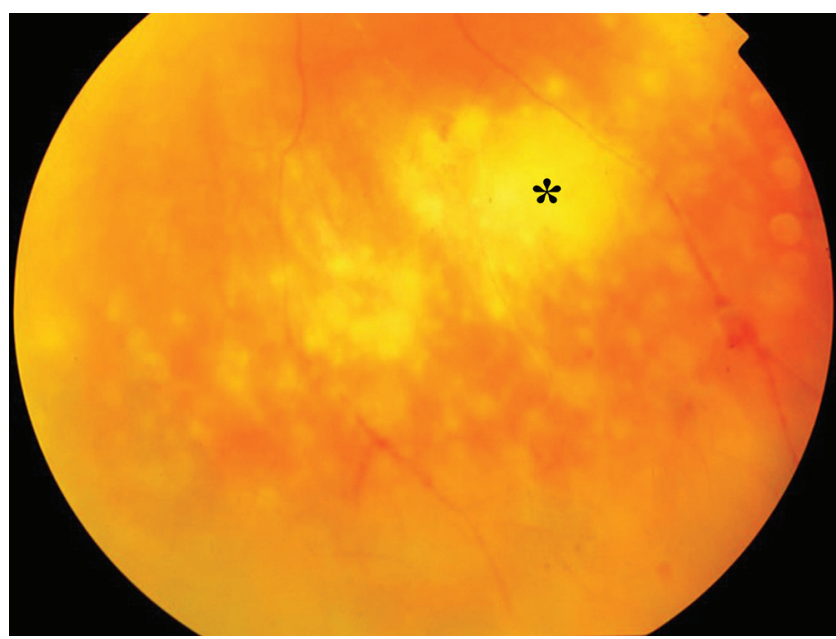

2. ábra

Szemfenéki kép: (alsó periféria) fehéres retinalis beszűrődések (csillag) mellett a szélső periférián kiterjedt ischaemiás terület látható. Az érfal gyulladása és az ischaemia miatt az erek mentén vérzések figyelhetők meg

amely mellett naponta végeztük követését, a neurológiai fekvőbeteg-gondozás korlátai között. A stroke etiológiájának további tisztázása érdekében liquormintavétel és koponya-MR-vizsgálat történt. A stroke-ot követő 5. napon végzett koponya-MR-vizsgálat a bal féltekei kis subcorticalis ischaemiás laesio (putamen, corona radiata területi infarktus) mellett a bal középső agyi artérián (arteria cerebri media) kontúregyenetlenséget írt le, egyéb ischaemiás laesio vagy érfali halmozás nem ábrázolódott. A stroke-ot követő 7. napon vett liquorból a herpesvírusok PCR-vizsgálata negatív eredménnyel zárult; a liquorszerológia enyhén emelkedett anti-VZVIgA-titert jelzett, és enyhe pleocytosis mutatkozott a mintában. A kezelés 9. napján (a stroke-ot követő 6. na-

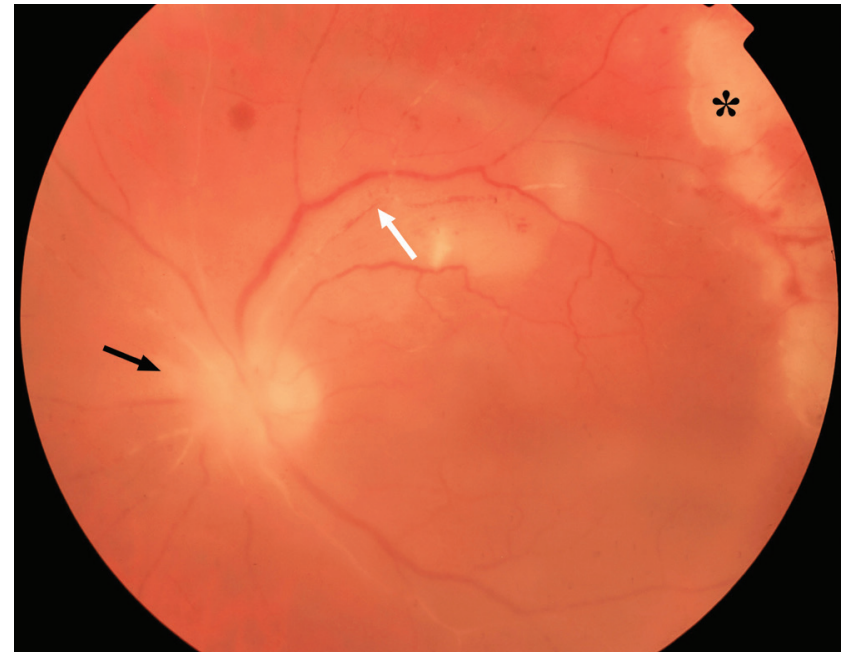

3. ábra

Szemfenéki kép: (hátsó pólus) a látóidegfó érintettsége mellett látható a kilépő artériák beszürtsége (fekete nyíl). A felső érágon az érfalban lerakódott immunkomplexek miatti (Kyrieleis-vasculitis) egyenetlen véroszlop fedezhető fel (fehér nyíl). A felső érágtól perifériásan ischaemiás terület (csillag)

pon) a megfelelő lassú infúzió és hidratálás ellenére a vesefunkció akut csökkenést mutatott, ezért az aciklovirkezelést feltételezett mellékhatás miatt fel kellett függeszteni. Ezt követően a vesefunkció fokozatosan rendeződött. A retina gyulladása a kezelés hatására megszűnt, az érintett retinaterületek egy temporalis kis maradvány kivételével atrofizálódtak, részben a látóidegfóvel együtt. Ennek következtében a látóképesség elveszett, fényérzésre redukálódott az érintett szemen. A súlyos szöveti destrukció ocularis hypotoniát okozott, amely miatt a később bekövetkezett lapos retinaleválás mütétének elvégzése nem volt vállalható. Másfél éves követés során recidíva vagy a másik szem érintettsége nem alakult ki, az ép szem látóélessége teljes. A beteg neurológiai tünetei mérsékelten regrediáltak tartós fizikoterápia mellett.

\section{Megbeszélés}

Az akut retinanekrózist Urayama írta le először 1971ben [4]. Az AAO a betegség kizárólag klinikai tünetekre alapozott diagnosztikus kritériumrendszerét 1994-ben foglalta össze (1. táblázat) [2]. Jellemző a magas aktivitás, a gyors progresszió, a recidíva, illetve a második szem érintettségének lehetősége. Esetünk a szemészeti standard kritériumok minden elemét egyesítette, a klinikai kép megfelelt az akut retinanekrózis típusos megjelenésének, ezért megalapozottan dönthettünk az intravénás, nagy dózisú antivirális kezelés azonnali bevezetése mellett. A bőrlaesiók hiánya - a „sine herpete” megjelenés lehetőségének ismerete $[5,6]$ alapján - nem zárja ki a VZV-patomechanizmus lehetőségét. A retinitis, retinalis vasculitis hátterében a leggyakoribb kórokozó a VZV, melyet a HSV1 és HSV2, a CMV és extrém ritkán az EBV követ [7]. A vérből végzett szerológiai vizsgálatban 
1. táblázat $\mid \mathrm{Az}$ akut retinanekrózis diagnosztikus kritériumai. Amerikai Szemorvostársaság (AAO), 1994 [2]

\begin{tabular}{ll}
\hline Diagnosztikus kritériumok & Diagnózist erősítő tényezők \\
\hline $\begin{array}{l}\text { A perifériás retinán egy vagy } \\
\text { több, diszkrét határú nekrotikus } \\
\text { beszűrődés }\end{array}$ & Víruskimutatás (PCR) \\
$\begin{array}{l}\text { Antivirális terápia nélküli gyors } \\
\text { progresszió }\end{array}$ & Vírusellenes antitestek kimutatása \\
Körkörös terjedés & $\begin{array}{l}\text { Fluoreszcens angiográfiával } \\
\text { igazolt occlusiv arteritis }\end{array}$ \\
$\begin{array}{l}\text { Arteriolákat érintő occlusiv } \\
\text { vasculopathia }\end{array}$ & $\begin{array}{l}\text { Maculaoedema, epiretinalis } \\
\text { membrán }\end{array}$ \\
$\begin{array}{l}\text { Jelentős üvegtesti gyulladás } \\
\text { vagy elülső uveitis }\end{array}$ & Kyrieleis-vasculitis \\
\hline
\end{tabular}

PCR = polimeráz-láncreakció

a VZV-IgG-pozitivitás mellett az -IgA- és -IgM-negativitás nem zárja ki a vírusreaktiváció lehetőségét, ha figyelembe vesszük, hogy az intraocularis és az intracranialis tér is szekvesztrált, a seroconversio nem feltétlenül mutatkozik kimutatható mértékben a szisztémás keringésben. A klinikai kép és a szerológiai vizsgálat alapján nem lehet mindig biztosan elkülöníteni a különböző kórokozók által okozott folyamatot, pedig terápiás érzékenységükben alapvető és lényegi különbségek vannak.

Az atípusos megjelenési formák igazolásában vagy a terápia meghatározásában fontos lehet a vírus azonosítása [8]. Ilyenkor nélkülözhetetlenek az intraocularis (csarnokvíz vagy üvegtesti) mintából végezhető szerológiai vizsgálatok: antitest-kimutatás, a GoldmannWitmer-koefficiens vizsgálata vagy a kórokozó-nukleinsav kimutatása PCR-vizsgálattal.

A stroke bekövetkezésekor felmerült az egyidejű patológiás folyamatok összefüggésének kérdése. Felvetettük az antivirális kezelés esetleges neurológiai mellékhatásának, a VZV központi idegrendszeri manifesztációjának, a VZV-vasculopathiának vagy egyéb, független kórfolyamatnak a lehetőségét.

Az aciklovirkezelés neurológiai mellékhatásai között nem találtunk stroke-ra vonatkozó egyértelmű adatot, a leginkább a tudatzavar változó mértékű formái fordulnak elő [9]. A kezelés neurológiai mellékhatása nagyon ritka, és csaknem mindig túladagolás vagy veseelégtelenség talaján kialakult toxikus szérumkoncentráció okozza [9]. Esetünkben a stroke bekövetkeztekor a beteg vesefunkciója fiziológiás volt, a gyógyszer szérumkoncentrációjának toxikus emelkedését kiváltó ok nem állt fenn. Az intraocularis mintából elvégzett PCR-vizsgálat bebizonyította a VZV jelenlétét, és alátámasztotta az adekvát kezelés folytatásának szükségességét.

Felmerülhetett továbbá a vírus intracranialis propagációja $[6,10]$. A neurológiai vizsgálat és a koponya MRvizsgálata VZV-encephalitis, -meningitis jeleit nem igazolta; az MR-vizsgálaton a bal oldali arteria cerebri mediában látott érfal-egyenetlenség felvetheti a vascularis érintettség lehetőségét. A herpesvírusok okozta intra- ocularis gyulladások esetében leírták a Kyrieleis-vasculitis jelenségét (immunkomplex-depozíció az érendothelben, mely az érfal megvastagodásával jár, fokozott thrombocytaaggregációhoz és érobliteratióhoz vezet) [11]. Ez a jelenség azonban nemcsak a retina ereiben, hanem a központi idegrendszer ereiben is mutatkozhat $[6,10$, 12]. A kiserek gyulladása MR-vizsgálattal kevéssé zárható ki, tehát az ischaemiás stroke hátterében ennek lehetősége fennáll. A stroke hátterében feltételezett gyulladásos patomechanizmus mellett szól a liquor pleocytosisa. A stroke-ot követő 7. napon vett liquorból végzett PCR-vizsgálat negativitása nem zárja ki a feltételezett VZV-patomechanizmust, tekintettel arra, hogy a folyamat kezdete, a kezdeti viraemia akár 3-4 héttel korábbra is tehető a fejfájásos panaszok alapján, és a beteg a szemészeti tünet miatt már 9 napja tartó antivirális kezelés alatt állt. Az időbeliség és a megelőző antivirális kezelés miatt is feltételezhető az esetleges kórokozószám-csökkenés és ezzel páthuzamosan a vizsgálat szenzitivitásának csökkenése, ami álnegativitást idézhet elő. A liquorszerológiában mutatkozott alacsony anti-VZVIgA-pozitivitás a vírus által kiváltott specifikus reakció fennállására utal. Irodalmi adat alapján a viraemia idején a PCR-vizsgálat szenzitivitása, a viraemia lezajlását követően a szerológiai vizsgálat szenzitivitása nagyobb $[6,10,13]$. A liquorszerológia enyhe anti-VZV-IgApozitivitása miatt a vizsgálat ismétlése, a seroconversio igazolása szükséges lett volna a központi idegrendszeri érintettség alátámasztására, azonban a beteg állapotára, a beavatkozás magas kockázatára, illetve a terápiás konzekvencia hiányára való tekintettel ismételt liquormintavétel nem történt.

A betegnek az anamnézisben szereplő diabetes mellitusa jól karbantartott, nem régóta fennálló, ismert szövődmény nélküli, vérnyomása pedig kezelés mellett a normáltartományban volt, ezért ezeknek a stroke kialakulásában játszott szerepe - bár nem zárható ki - kisebb valószínúségú. Ugyanakkor a diabetes talaján lehetséges immunhiány elősegíthette a vírusreaktivációt és a központi idegrendszeri terjedést.

Ismereteink folyamatosan növekednek a herpes zoster okozta akut és postherpeses tüneteket illetően. Irodalmi adatok tanúsága alapján úgy tünik, hogy korábban a VZV és a központi idegrendszeri ischaemiás eltérések kapcsolatát jelentősen alábecsültüik.

Az irodalomban fellelhető adatok alapján a VZV-infekcióhoz jelentősen emelkedett gyakorisággal társulhat stroke $[14,15]$. Azokban a betegekben, akiknél nervus V/I-es zosterfertőzés zajlott le, a stroke kockázata az egyéb zosteres manifesztációkéhoz képest magasabb [6, 10, 12, 16]: az első 2 hétben a legkifejezettebb, azonban a kontrollcsoporthoz képest még 5-12 héttel a kezdeti tünetek megjelenése után is háromszoros a rizikó [15, 17]. Ez a szorzó még magasabb gyermekkorban, amikor a központi idegrendszeri vascularis történések összességében sokkal ritkábbak. Braun a 2008. évi cikkében kimutatta, hogy gyermekkorban az ischaemiás agyi tör- 
ténéseket 44\%-ban előzi meg (1 éven belüli) varicellafertőzés [18]. A központi idegrendszeri tünetek a leggyakrabban 6 héten belül jelentkeznek, de több hónappal, akár évekkel az első tünetek megjelenése után is kialakulhatnak késői eltérések [19].

A VZV reaktivációjakor a viraemia fázisában a vírus axonalis úton direkt módon eljuthat a központi idegrendszer szöveteibe, illetve az ereket ellátó idegek menetén az érfalba is $[6,10,12,16]$. Az intracerebralis artériák gazdag ellátást kapnak a nervus trigeminus ágrendszeréből, így a V/I-es ág területén jelentkező zoster alatt a reaktiváció ezeket az ereket is elérheti [20]. Ezt az intracranialis erek falának szövettani vizsgálatával kimutatott Cowdry A-típusú nukleáris zárványtestek jelenléte is alátámasztja $[6,10,21]$. A vírus elleni védekezés során az érfalban immunkomplexek lerakódását találták, mely az érfal bogyós intraluminalis megvastagodásához (a szemfenéken is látható és érfestéses vizsgálattal igazolható Kyrieleis-vasculitis), endothelsérüléshez, thrombocytaaggregációhoz és elzáródáshoz vezet [21]; másrészt az érendothelben a vírus jelenléte primer granulomatosus vasculitist okozhat. A vasculitises folyamat a viraemia lezajlása után később is jelentkezhet, amikor a beteg az akut tünetek szempontjából már panaszmentesnek tünik [22].

A VZV-vasculopathia manifeszt tünete az ischaemiás (nagyon ritkán vérzéses) stroke, de a betegek beszámolnak erőteljes fejfájásról, kognitív romlásról és bizonytalanságérzésről is. A VZV okozta érkárosodás gyanúja általában a neurológiai tünetek megjelenésekor merül fel, amennyiben a beteg kórtörténetében a közelmúltban lezajlott herpes zoster szerepel, illetve a képalkotó vizsgálat érkárosodást, -szúküuletet vagy -elzáródást, érfalegyenetlenséget jelez. Ezen tényezők fennállása esetén mindenképpen ajánlott a liquoranalízis elvégzése. Korábban a VZV-nukleinsav-kimutatást tartották a betegség szempontjából diagnosztikusnak. Nagel 2008. évi összefoglaló közleménye alapján a kimutatott, típusos cerebralis érkárosodás esetén a liquorból végzett PCRvizsgálat az esetek 30\%-ában mutatott pozitivitást, míg ugyanezen esetekben a szerológiai vizsgálat 93\%-ban mutatott intrathecalis VZV elleni antitest pozitivitást $[6,10,13]$.

\section{Következtetés}

Bemutatott esetünkben az anamnézisben szereplő, azonos oldali erős fejfájás, a „sine herpete” folyamatot követô típusos és kifejezett, fulmináns akut retinanekrózis, a koponya-CT-vel kimutatott - az agyi infarktus szempontjából releváns lokalizációjú - intracranialis artériafalegyenetlenség és a liquorszerológiai vizsgálattal észlelt VZV-IgA-pozitivitás alapján felmerül a központi idegrendszert érintő kialakult ischaemiás történés hátterében az irodalom által körülírt VZV-vasculopathia lehetősége. Esetünk teljesíti ennek 3 kritériumát: VZV-fertőzés fennállása, neurológiai tünet és a képalkotó vizsgálat po- zitivitása, továbbá az ezekhez társuló (bár gyenge) liquor-szeropozitivitás.

A szteroid alkalmazása akut retinanekrózisban mindmáig vitatott kérdés. Izolált, súlyos szemészeti manifesztációban szteroid adása további vírusreplikációt indukálva fokozhatja az intracranialis terjedés kockázatát. A betegségtársulás átfogóbb ismerete, az MR- és a PCRvizsgálat korábbi elvégzése megalapozottabbá teheti a diagnózist, és a már szemészeti indikációval nagy dózisban megkezdett antivirális kezelés mellett a központi idegrendszeri, illetve vascularis érintettségben elfogadott kiegészítő szteroidterápia kedvezőbb kimenetelt eredményezhet a neurológiai következmények tekintetében.

Esetünk ismertetésével szeretnénk felhívni a figyelmet a VZV által okozott - bőrtüneteken túlmutató - potenciálisan súlyos betegségmanifesztációkra, illetve a VZVvasculopathia által előidézett, a klinikai gyakorlatban alábecsült gyakoriságú, életet veszélyeztető szövődmények lehetőségére.

Bár irodalmi adatok alapján ismert az V/I-es agyideget érintő varicella zoster, a VZV-vasculopathia és a következményes stroke kapcsolata, de az akut retinanekrózis és a VZV okozta központi idegrendszeri stroke társulására vonatkozó közlést nem találtunk.

Fontosnak tartottuk továbbá, hogy a szemfenéken látható éreltérések (Kyrieleis-vasculitis, érelzáródás, ischaemia) pontos megfelelői a központi idegrendszerben lejátszódó folyamatoknak is. Szeretnénk hangsúlyozni, hogy ennek a betegségtársulásnak az ismerete nem kizárólag a szemészek számára jelentős, hanem a bőrgyógyászok, infektológusok, neurológusok, angiológusok és belgyógyászok számára is elengedhetetlen, mivel az ehhez hasonló klinikai esetek feltételezhetően az eddig felismertnél gyakrabban fordulnak elő, de eredményes kezelésük feltétele az interdiszciplináris megközelítésen alapuló gyors diagnózis.

Anyagi támogatás: A közlemény megírása, illetve a kapcsolódó kutatómunka anyagi támogatásban nem részesült.

Szerzői munkamegosztás: Kezelőorvos: D. J., G. B., M. M. A mütét elvégzése: R. M. Képalkotó leletezés és véleményezés: R. G. A közlemény megírása, irodalomkutatás: M. M., D. J. A közlemény kritikai revíziója: D. J., G. B., N. Z. Zs. A cikk végleges változatát valamennyi szerző elolvasta és jóváhagyta.

Érdekeltségek: A szerzőknek nincsenek érdekeltségeik.

\section{Irodalom}

[1] Kennedy PG. Zoster sine herpete: it would be rash to ignore it. Neurology 2011; 76: 416-417.

[2] Holland GN, Executive Committee of the American Uveitis Society. Standard diagnostic criteria for the acute retinal necrosis syndrome. Am J Ophthalmol. 1994; 117: 663-666. 
[3] Anthony CL, Bavinger JC, Yeh S. Advances in the diagnosis and management of acute retinal necrosis. Ann Eye Sci. 2020; 5: 28.

[4] Urayama A, Yamada N, Sasaki T, et al. Unilateral acute uveitis with retinal periarteritis and detachment. Jpn J Clin Ophtalmol. 1971; 25: 607-619.

[5] González-Otárula KA, Bruno V, Pujol-Lereis VA, et al. Cerebral varicella-zoster vasculopathy sine herpete: atypical Ramsay-Hunt syndrome in an immunocompetent patient. Neurol Clin Pract. 2014; 4: 260-262.

[6] Kleinschmidt-DeMasters BK, Gilden DH. Varicella-zoster virus infections of the nervous system: clinical and pathologic correlates. Arch Pathol Lab Med. 2001; 125: 770-780.

[7] Powell B, Wang D, Llop S. Management strategies of acute retinal necrosis: current perspectives. Clin Ophthalmol. 2020; 14 1931-1943.

[8] Wensing B, de Groot-Mijnes JD, Rothova A. Necrotizing and nonnecrotizing variants of herpetic uveitis with posterior segment involvement. Arch Ophthalmol. 2011; 129: 403-408.

[9] Rashiq S, Briewa L, Mooney M, et al. Distinguishing acyclovir neurotoxicity from encephalomyelitis. J Intern Med. 1993; 234: 507-511.

[10] Gilden DH, Bennett JL, Kleinschmidt-DeMasters BK, et al. The value of cerebrospinal fluid antiviral antibody in the diagnosis of neurologic disease produced by varicella zoster virus. Neurol Sci. 1998; 159: 140-144.

[11] Francés-Muñoz E, Gallego-Pinazo R, López-Lizcano R, et al. Kyrieleis' vasculitis in acute retinal necrosis. Clin Ophthalmol. 2010; 4: 837-838.

[12] Hilt DC, Buchholz D, Krumholz A, et al. Herpes zoster ophthalmicus and delayed contralateral hemiparesis caused by cerebral angiitis: diagnosis and management approaches. Ann Neurol. 1983; 14: 543-553.

[13] Nagel MA, Cohrs RJ, Mahalingam R, et al. The varicella zoster virus vasulopathies: clinical, CSF, imaging and virologic features. Neurology 2008; 70: 853-860.
[14] Lin HC, Chien CW, Ho JD. Herpes zoster ophthalmicus and the risk of stroke: a population-based follow-up study. Neurology 2010; 74: 792-797.

[15] Sreenivasan N, Basit S, Wohlfahrt J, et al. The short- and longterm risk of stroke after herpes zoster - a nationwide populationbased cohort study. PLoS ONE 2013; 8: e69156.

[16] Terborg C, Busse O. Granulomatous vasculitis of the CNS as a complication of herpes zoster ophthalmicus. [Die granulomatöse Vaskulitis des ZNS als Komplikation des Herpes zoster ophthalmicus (HZO).] Fortschr Neurol Psychiatr. 1995; 63: 383-387. [German]

[17] Marra F, Ruckenstein J, Richardson K. A meta-analysis of stroke risk following herpes zoster infection. BMC Infect Dis. 2017; 17: 198.

[18] Braun KP, Bulder MM, Chabrier S, et al. The course and outcome of unilateral intracranial arteriopathy in 79 children with ischemic stroke. Brain 2009; 132: 544-557. [Epub 2008 Nov 27]

[19] Miravet E, Danchaivijitr N, Basu H. Clinical and radiological features of childhood cerebral infarction following varicella zoster virus infection. Dev Med Child Neurol. 2007; 49: 417-422.

[20] Saraya T, Shimura C, Wada H, et al. Evidence for vascular spread of varicella zoster-associated vasculopathy. Ann Intern Med. 2006; 144: 535-537.

[21] Amlie-Lefond C, Gilden D. Varicella zoster virus: a common cause of stroke in children and adults. J Stroke Cerebrovasc Dis. 2016; 25: 1561-1569.

[22] Nagel MA, Bubak AN. Varicella zoster virus vasculopathy. J Infect Dis. 2018; 218(Suppl 2): S107-S112.

(Magyar Márton dr., Budapest, Mária u. 39., 1085 e-mail: dr.magyarmarton@gmail.com)

A cikk a Creative Commons Attribution 4.0 International License (https://creativecommons.org/licenses/by/4.0/) feltételei szerint publikált Open Access közlemény, melynek szellemében a cikk bármilyen médiumban szabadon felhasználható, megosztható és újraközölhető, feltéve, hogy az eredeti szerző és a közlés helye, illetve a CC License linkje és az esetlegesen végrehajtott módositások feltüntetésre kerülnek. (SID_1) 